\title{
Characteristics and Behavior of Managers towards Cost Consciouness (Empirical studies on Leadership Working Units in Southern Kalimantan Provincial Government)
}

\author{
ADE ADRIANI AND NORLENA
}

\begin{abstract}
The research's purpose is to test empirically examine the effect of the regional financial accounting information system characteristics and behavior of managers towards cost consciouness in the use of financial information systems area. Manager behavior is proxied by the control decision-making and cost management consciousness as practiced by Abernethy and Emidia. The study will examine whether the phenomenon occurs in Indonesia, particularly in the South Kalimantan provincial government. Concretely influences the characteristics of accounting information systems in this area of financial information systems, it is seen from the behavior of Chief SKPD in the South Kalimantan provincial government in decision-. The Result shows that Characteristics of Financial Accounting Information Systems affect the use of the local financial system to control decision-making and management. There is a significant relationship between system characteristics financial information to the control area decisions. Financial regionally accounting information system characteristics were positively associated with decision controlling policy. The use of financial information systems area for menajament decisions affect cost consciousness. The effect of control decisions the cost consciousness is significant.
\end{abstract}

Keywords : Financial Regionally Accounting Information System Characteristics, decision controlling policy, decision management policy, cost conciousness.

\section{INTRODUCTION}

Characteristics of information in the accounting system used to control the behavior of managers and decision-making (Antony, 1965; Chenhall and Morris, 1986; Milgrom and Roberts, 1992; Bowens and Abernerthy, 2000). Correspondence between the information needs of decision-making to support quality decision to be taken, which in turn can improve the performance of the company (Nedler and Tushman, 1988). Selection of information system design is also a significant impact on costs as a result of decisions made by managers. Assessment decision that comes from formal authority over the input and output effect on commitment and purpose of the system associated with cost efficiency (Steer, 1977), .

Election information systems design is also a significant impact on costs as a result of decisions made by managers. Assessment decision that comes from formal authority over the input and output effect on commitment and purpose of the system associated with cost efficiency (Steer, 1977 in Abernethy and Emidia, 2004).

This study aims to empirically examine the effect of the regional financial accounting information system characteristics and behavior of managers towards cost consciouness in the use of financial information systems area. Manager behavior is proxied by the control decision-making and cost management consciousness as practiced by Abernethy and Emidia (2004). The study will examine whether the phenomenon occurs in Indonesia, particularly in the South Kalimantan provincial government. Concretely influences the characteristics of accounting information systems in this area of financial information systems, it is seen from the behavior of Chief SKPD in the South Kalimantan provincial government in decision-making. The population of this study are all leaders / heads SKPD in South 
Kalimantan Provincial Government. The unit of analysis of this study is the leadership (as an individual) strukutral positions and the respondent is the head of the budget users SKPD as officials with due consideration SKPD Chief has the authority in the management of revenue and expenditure budget in which they are involved from planning to execution of the budget, which allows them to influence the attitudes towards costs that may be incurred.

Based on this background, this study wanted to examine the effect of regional financial accounting information system characteristics for managerial behavior. Manager behavior is proxied by the control decision-making and cost management consciousness as practiced by Abernethy and Emidia (2004). The study will examine whether the phenomenon occurs in Indonesia, particularly in the South Kalimantan provincial government. Concretely influences the characteristics of accounting information systems in this area of financial information systems, it is seen from the behavior of the Head of Regional / Agency / Office / Department in the decision.

\section{METHODS}

This research uses explanatory methods that aim to test hypotheses about the relationship between the influence of different variables under study based on data obtained in order to get the meaning and implications of the problems to be solved in a systematic, timely and reliable (Cooper \& Scindler, 2006). The population of this study are all leaders / heads SKPD in South Kalimantan Provincial Government according to the number SKPD by South Kalimantan Provincial Regulation No. 1 of 2012. The unit of analysis of this study is the leadership (individual/person) strukutral positions and the respondent is the head of the budget users SKPD as officials with due consideration SKPD Chief has the authority in the management of revenue and expenditure budget in which they are involved from planning to execution of the budget, which allows them to influence the attitudes towards costs that may be incurred.

The data used in this study are all primary data. The procedure of data collection in this study using field research or survey research. The primary data from the respondents' answers to questionnaires sent to respondents consisting of head / head SKPD directly related to the budget in South Kalimantan government. The questionnaire used is a questionnaire that has been used by previous researchers. Distribution and collection of questionnaires carried out by distributed directly to the respondents. The time is determined from the distribution of questionnaires to the return is 1 month. This time limit may be enough to do the research because domislili respondents centered on the town.Path Analysis using regression analysis was used to test the study hyphoteses. Data analysis was performed using multiple regression analysis with the help of Statistical Software Program Product and Service Solution (SPSS) version 17.

\section{RESULT}

A path of model highliting association among financial regionally accounting information system characteristics and behavior of managers toward cost consciouness and the summary of hyphotesized relationship are presented in figure 1 : 


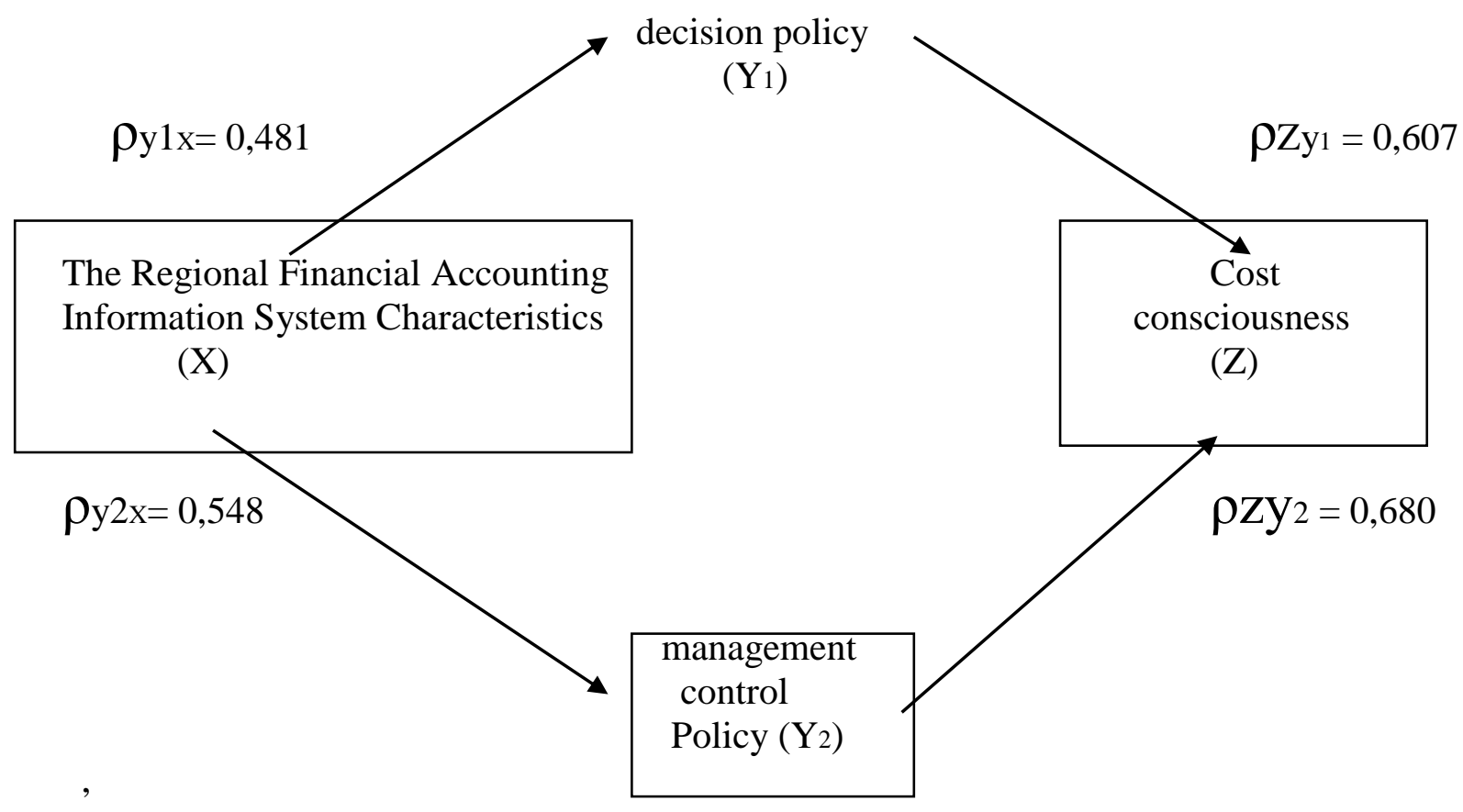

Figure $1:$ summary of hyphotesized relationship

Hypothesis 1a states that the characteristics SIKD positive effect SIKD use to control decisions. The test results of the regression model indicated that the financial regionally accounting information system characteristics was positively related to decision controlling policy $(\mathrm{p}<0,001)$ which provides adequate statistical support for Hyphotesis 1a

Testing Hypothesis 1a shows a significant relationship between system characteristics financial information to the control area decisions. The findings are consistent with research Milgron and Roberts (1992) also conducted by Chairina (2005) and Julita (2007). This study does not support the research and Emidia Abernethy (2004) and Syafruddin (2006) who found that there was no significant effect between the characteristics of the control SIKD decision.

Hypothesis $1 \mathrm{~b}$ states that the characteristics SIKD positive effect

The test results of the regression model indicated that the financial regionally accounting information system characteristics was also positively related to the decision management policy $(\mathrm{p}<0,001)$ which provides adequate statistical support for Hyphotesis $1 \mathrm{~b}$. The results of the analysis suggested that financial regionally accounting information system characteristics were positively associated with decision controlling policy.

Testing the hypothesis $2 \mathrm{~b}$ shows a significant relationship between the characteristics of financial information systems management area with the decision.

The findings are consistent with research and Emidia Abernethy (2004) and Syafruddin (2006). The results of this study do not support the results of research conducted by Chairina (2005) and Julita (2007), who found that there was no significant effect of the characteristics of financial information systems to the management area.

Testing hypotheses 2 a shows that the effect of control decisions the cost consciousness is significant. The results of this study are consistent with Chairina (2005) but does not support the research conducted Julita (2007). The results of this study indicate that the lack of concern by the Head of the Regional cost or cost concerns led SKPD which is an 
important first step for the creation of a local government organization accountable, transparent and clean. Care costs can be used to measure the performance of the working unit heads in the assessment of effectiveness and efficiency in the management of routine activities that should be the regional head office and working unit heads further enhance its ability in terms of cost concerns.

Testing the hypothesis $2 b$ shows that the influence of management of decision the cost consciousness is significant. The results of this study are consistent with the research done and Emidia Abernethy (2004), Syafruddin (2006) and Julita (2007). The results of this study support the research Birnberg et. al, (1990), that the cost be an important consideration in the decision and the manager attempts to achieve cost efficiency of tighten budget. Concern for employees memotovasi costs are expected to take action to reduce long-term costs but pushing them at risk of short-term

\section{CONCLUSIONS}

1.Characteristics of Financial Accounting Information Systems affect the use of the local financial system to control decisionmaking and management. There is a significant relationship between system characteristics financial information to the control area decisions. The findings are consistent with research Milgron and Roberts (1992) also conducted by Chairina (2005) and Julita (2007).Financial regionally accounting information system characteristics were positively associated with decision controlling policy. The findings are consistent with research and Emidia Abernethy (2004) and Syafruddin (2006).

2. The use of financial information systems area for menajamen decisions affect cost consciousness. The effect of control decisions the cost consciousness is significant. The results of this study are consistent with Chairina (2005) but does not support the research conducted Julita (2007). the influence of management of decisionthe cost consciousness is significant. The results of this study are consistent with the research done and Emidia Abernethy (2004), Syafruddin (2006) and Julita (2007).

\section{Implications :}

1. This study has broad implications in the future and expected to be useful as a material consideration in behavioral accounting in Indonesia in improving the efficiency of an organization.The results could be a contribution to the South Kalimantan provincial government as well as to be used as inputs in performing routine activities primarily related to cost efficiency improvements to decisionmaking so that local government performance can be improved.

2. The results of this study are expected to contribute to the development of literature in the field of behavioral accounting, in particular the behavior of cost consciousness so as to increase cost efficiency, as well as the motivation to do next research primarily related to cost consciousness

\section{REFERENCES}

Abernethy, M. A., \& Chua, W. F. (1996). A Feld Study of Control System "Redesign": The Impact of Institution Al Processes On Strategic Choice. Contemporary Accounting Research, 13, 596 - 606. \& Emidia Vagnoni (2004). Power, Organization design and Managerial 
Behaviours Organizations. Accounting, Organization and Society, 29, 207 - 225. \& Lilis, A. M. (2001). Interdependencies In Organization Design : A Test In Hospitals. Journal of Management Accounting Research, 13, $107-130$.

, \& M. A. Lilis A. M., Brownell, P., \& Carter, C. (2001). Product Diversity and Costing System Design Choice : Field Study Evidence. Management Accounting Research, 12 (3), 261 - 279. , \& M. A., \& Stoelwinder, J. U. (1995). The Role of Professional Control In The Management of Complex Organizations. Accounting, Organization and Society, 20 (1), 1 - 17.

Harris. J. E. (1997). The internal organization of hospitals: some economic implications. The Bell Journal of Economics, 32, 349410.

Agraris, C. (1995). The Impect of Budgets on People. Ithaca New York. The Controllership Foundation Inc. Cornell University.

Alexander, J. A., \& Morlock, L. L. (2000). Power and Politics In Health Services Organizations, In Health Care Management : Organization Design And behaviour $\left(4^{\text {th }} E d\right)$. Albany, $\mathrm{Ny}$ : Thompson Learning.

Anthony, R. A. (1965). Planning and Control System : A Framework For Analysis. Boston : Harvard University Press.

Augusty Ferdinan (2002), Structure Equation Modeling dalam Penelitian Manaje 105 BP UNDIP.

Arya, A., J, Glover, and K. Sivaramakrshnan, 1997. The Interaction between decision and control problems and the value of information. The Accounting Review.

Barnard, C. I. (1968). The Function of the Executive (30 th Anniversary Edition). Cambridge : Harvard University Press.

Bouwens, J., \& Abernethy, M. A. (2000). The consequences of customization of management accounting system design.
Accounting, Organization and Society, 24 (2), $221-241$.

Bruns, W., J., \& Waterhouse, J. H. (1975). Budget Control and Organization Structure. Journal of Accounting Research, 13 (2). $177-203$.

Chairina, 2005, Pengaruh Kekuasaan, Desain Organisasi dan Perilaku Manajer Terhadap Cost Consciousness, Tesis Program Pasca Sarjana, Magister Sains Akuntansi Undip. (tidak dipublikasikan)

Chia, Y.M. (1995). Desentralization Management Accounting System (MAS) Information Characteristic and their Interaction Effects on Managerial P. Desentralization Management Accounting System (MAS) Information Characteristic and their Interaction Effects on Managerial Performance; A Singapore Study. Journal of Business Finance and Accounting. Sept. pp $881-830$.

Chenhall, R. H., \& Morris, D. (1986). The Impact of Structure, Environment and Interdependence On the Perceived Usefulness of Managemen T. The Accounting Review, 61 (2), 263 - 272.

Cyert, R. M., \& March, J. G. (1963). A Behavioral Theory of the Firm. Englewood Cliffs, Ny : Prentice- Hall.

Covaleski, M. A. \& Dirsmith, M. W. (1986). The Budgetary Process of Power and Politics. Accounting, Organization and Society, 11 (3), $193-214$.

Direktorat Jenderal Perimbangan Keuangan. (2011). Monitoring dan Evaluasi Penyelenggaraan Sistem Informasi Keuangan

Daerah.http://www.djpk.depkeu.go.id/data djpk/123/

Ending, R. (2004). Analisis Pengaruh Ketidakpastian Lingkungan dan Kultur Organisasional sebagai Variabel Moderating Terhadap Hubungan Informasi Akuntansi Terhadap Kinerja Manajer. Thesis Program Pascasarjana Magister Sains Akuntansi Universitas Diponegoro (Tidak Dipublikasikan). 
Flamholz, E., T. D., \& Tsui, A. S. (1985). Toward An Integrative Framework of Organizational Control. Accounting, Organization and Society, 10 (1), 35 - 50.

Freidson, E. (1975). Dotoring Together : a Study of Professional Control. Chigago : University of Chigago Press.

Frucot, V,. and Shearon. W. T., (1991). Bugetery Participation, Locus of Control, and Mexican Manajerial Performance and Job Satisfiction. The Accounting Review, January, h. 3 - 19.

Govindarajan, V. (1988). A Contingency Approach to Strategy Implementation at the Business - Unit Level : Integrating Administrative Mechanisms with Strategy. Academy of Management Journal, 31 (4), $828-853$.

Harris, J. E. (1997). Internal Organization of Hospitals : Some Economic Implications. The Bell Journal of Economics, 8 (2), 467 -482 .

Harrison, G.I., and J. L. Mckinnon., (1991). Culture and Accounting Change : A New Perspective on Corporate Reporting Regulation and Accounting Policy Formulation.

Hofstede, G., (1980). Culture's Consequences : International Differences in workReleted Values, London : Sage Publication.

Homess, S. W., Marsden (1996). An Exploration of the Espoused Organization Culture of Public Accounting Firms. Accounting Horizons, Sept, h. $12-20$.

Imam Ghozali (2004), Model Persamaan Struktural : Konsep dan Aplikasi dengan program AMOS Ver. 5.0. Universitas Diponegoro.

Ittner, C. D., \& Larcke, D. F. (2001). Assessing Empirical Research In Managerial Accounting: A Value - Based Management Perspective. Journal of Accounting and Economics, 32, 349 - 410.

Jensen, M.C. (1998). Foundation of Organizational Strategy. Cambridge, Ma : Harvard University Press.
Jensen, M. C., \& Meckling, W. H. (1992). Specific and General Knowledge and Organizational Stucture. In. L. Werin, \& H. Wijkander (Eds), Contract Economics. Cambridge : Blackwell Publishers.

Khomsiyah \& Nur Indriyantoro (2000). Aspek Perilaku Penganggaran Partisipatif. Jurnal Akuntansi dan Auditing Indo. Vol. 3 No. 2 Des. Pp. 123 - 133.

Kotter, J. P. (1985). Power and Influence : Beyond Formal Authority. New York : Free Press.

Kren, L. (1997). The Role of Accounting Information In Organizational Control : The State of the Art. In. V. Arnold, \& S. G. Sutton (Eds), Behavioral Accounting Research, Foundations and Frontiers. American Accounting Assosiation : USA.

Kurunma Ki, L. (1999). Professional VS Financial Capital In The Eld of Health Care - Struggles For The Redistribution of Power and Control. Accounting Organization and Society, 24 (2), 95 - 124.

Luft, J., \& Shields, M. (2003). Mapping management accounting : making structural models from theory - based empirical research. Accounting Organizations and Society, 28, $169-250$.

Luthans, F., (1995). In Organizational Behavior. Mc Grow - Hill.

Macintosh, N. B., \& Williams, J. J. (1992). Managerial Roles and Budgeting Behaviour. Rehavoial Research In accounting \& Management, 12 (3), Agust, pp $173-189)$.

Mardiasmo. (2009). Akuntansi Sektor Publik, Yogyakarta : Penerbit ANDI .

Merchant, K. A. (1981). The Design of the Corporate Budgeting System :Influences on Managerial Behavior and Performance. The Accounting Review, 56, 813 - 829.

Mia. L., and N. Miah (1996) Desentralization, Accounting Control and Performant of Government Organization : A New Zealand Empirical Study. Financial Accounting \& Management, 12 (3), Agust, pp 173 - 189. 
Milgrom, P., Roberts, J. (1992). Economics, Organization and Management. Englewood Cli. S, $\mathrm{Nj}$ : Prentice - Hall International.

Milliken, F. J. (1990), Perceving and Interpreting Environment Change : An Examination of Collage Administrator's Interpretation of Changing Demographics. Academy of Management Journal, h. 42 63.

Mintzberg, F. J., (1990). The Design School : Reconsiding the Basic Premises of Strategic Management. Strategic management Journal, h. 171 - 195.

Otley, D. T., (1980). The Contogency Theory of Management Accounting Achievement and Prognosis. Accounting, Organization and Society. h. $412-428$.

Pfeffer, J. (1992). Managing With Power: Politics and Influence Inorganizations. Boston : Harvard Business Press.

Robbins, Stephen P., (1996). Organizational Behavior : Concept, Controversies, aplication. Eight Edition, Pretice Hall, Inc.

Shields, M. D. (1997). Research in Management Accounting by North Americans in the 1990s. Journal of Management Accounting Research, 9, 3 61.

Shields, M., \& Young, S. M. (1994). Managing Innovation Costs : A Study of Cost Conscious behavior by $\mathrm{R} \& \mathrm{D}$ Professionals. Journal of Manag 107 Accounting Research, 6 175, 196.

Simons, RR. (1995). Levers of Control: How Managers Use Innovative Control System to Drive Strategic Renewal. Boston : Harvard Business School Press.
Steers, R. M. (1977). Organizational Efectiveness : A Behavioral View. Santa Monica : Goodyear.

Suwardjono. (2005). TEORI AKUNTANSI : Perekayasaan Laporan Keuangan.Edisi Ketiga,Yogyakarta : BPFE

Swieringa, R. J., \& Moncur, R. H. (1975). The Relationship Between Manager's Budget Related Behavior and Selected attitude, Positions, Size and Perfomance Measures. Empirical Research In Accounting : Selected Studies, Supplement to Journal of Accounting Review, 10, 194 205.

Weiner, S. L., Maxwell, J. H., Sapolsky, H. M., Dunn, D. L., \& Hsiao, W. C. (1987). Economic Incentives and Organizational Realities : Managing Hospitals Under Drugs. Milbank Memorial Fund Quarterly, 65 (4), 463 - 487.

Wruck, K., \& Jensen, M. C. (1994). Science, Speci. C. Knowledge, and Total Quality Management. Journal of Accounting and Economics, 18 (3), 247 - 287.

Yohanes, M. (2002). Motivasi dan Pelimpahan Wewenang Sebagai Variabel Moderating Dalam Hubungan Antara Partisipasi penyusunan Anggaran dan Kinerja Manajerial. Thesis Program Pascasarjana Magister Sains Akuntansi Universitas Diponegoro (Tidak Dipublikasikan).

Young., D. W., \& Saltman, . B. (1985). The Hospital Power Equilibrium, Physician Behavior and Cost Control. Baltimore : Johns Hopkins University.

Zimmerman, J. (1997). Accounting for Decision Making and Control. Boston : Irwin / McGraw Hill. 